\title{
Polyol Modification of PEDOT: PSS as Hole Transport Material Affects the Performance and Stability of Calcium Titanate $\left(\mathrm{CaTiO}_{3}\right)$ Solar Cell and UV Photodetector
}

\author{
Lusi Ernawati ${ }^{1 *}$, Alfonsina Abat Amelenan Torimtubun ${ }^{1}$, Teguh Arofai ${ }^{1}$, Adhya Yani $^{1}$, \\ Thorikul $\mathrm{Huda}^{2}$, and Ruri Agung Wahyuono ${ }^{3,4}$ \\ ${ }^{1}$ Department of Chemical Engineering, Institut Teknologi Kalimantan, Jl. Soekarno Hatta, \\ Balikpapan 76127, East Kalimantan, Indonesia. \\ ${ }^{2}$ Department of Electrical Engineering, Institut Teknologi Kalimantan, Jl. Soekarno Hatta, \\ Balikpapan 76127, East Kalimantan, Indonesia. \\ ${ }^{3}$ Department of Engineering Physics, Institut Teknologi Sepuluh November, Jl. Teknik Kimia, \\ Surabaya 60111, East Java, Indonesia \\ ${ }^{4}$ Institute of Physical Chemistry, Friedrich Schiller University, Fürstengraben 1, \\ 07743 Jena, Germany
}

\begin{abstract}
This report a novel and straightforward architecture of $\mathrm{CaTiO}_{3}-$ based solar cells with optimized hole transport material (HTM) properties. The perovskite $\mathrm{CaTiO}_{3}$ particle was prepared via the solution process using different $\mathrm{CaCO}_{3} / \mathrm{TiO}_{2}$ ratios. The design of $\mathrm{CaTiO}_{3}$-based solar cell follows the inverted architecture, in which poly (4-styrene sulfonate)-doped poly (3,4-ethylenedioxy-thiophene (PEDOT:PSS) and PCBM-C70 were used as HTM and electron transport layer (ETL), respectively. Charge mobility of HTM was modified and improved by using either ethylene glycol (EG) or diethylene glycol (DEG). The optimum condition of $\mathrm{CaTiO}_{3}$-based solar cell was obtained using $\mathrm{CaCO}_{3} / \mathrm{TiO}_{2}$ ratio of $(1: 7)$ annealed at $900{ }^{\circ} \mathrm{C}$ and $44.4 \%(\mathrm{v} / \mathrm{v})$ DEG-modified PEDOT/PSS. The conversion efficiency of $3.1 \%$ with a stable solar cell performance up to $72 \mathrm{~h}$ under the ambient condition without encapsulation was achieved.
\end{abstract}

Keywords: Electron transport layer, inverted structure, Perovskite $\mathrm{CaTiO}_{3}$ particle, perovskite solar cell, polyol alteration.

\section{Introduction}

Renewable energy utilization is considered an alternative solution to reduce environmental issues such as global warming and climate change due to the intensive use of fossil fuels. Among various renewable energy resources and conversion technology, solar energy

\footnotetext{
*Corresponding author: lusiernawati@lecturer.itk.ac.id
} 
conversion using photovoltaic (PV) has been a mature technology for future global green energy production [1,2]. Thus, extensive researches have been geared to develop new materials for green energy applications. Perovskite solar cell (PSC) is an emerging solar cell technology that has already reached high efficiency since its seminal report [1]. Nonetheless, the current drawbacks of this solar cell are the use of lead halide perovskite, which features high environmental toxicity $[1,2]$. Also, PSCs also show lower stability due to the degradation of organic molecules upon aging and irradiation. Therefore, one of the recent studies focuses on the development of $\mathrm{Pb}$-free perovskite and stable solar cell performance.

Another direction to optimize the PSCs performance is to stabilize charge-separated states created upon light absorption by active perovskite layer: The excited state electron is donated to the electron transport layer (ETL), such as phenyl-C70-butyric acid methyl ester (PC70BM), while the hole is transferred to hole transport layer (HTL). Particularly for HTL poly(4-styrene sulfonate)-doped poly(3,4-ethylenedioxy-thiophene) (PEDOT:PSS) is intensively utilized in PSC [3, 4]. This material exhibits high conductivity, high transparency, and hole affinity [5-7]. Also, the molecular structure of PEDOT:PSS allows us to have a good photo and electrical-stability in an ambient atmosphere [7]. When integrated into PSC, a very high charge mobility is required for PEDOT:PSS since the hole needs to escape from recombination reaction with the electron residing on ETL and hence, creates more stable charge-separated states. Furthermore, the coating of PEDOT:PSS onto the photoactive layers remains to be one of the main technical challenges involved in the fabrication of these devices $[8,9]$.

In order to improve the properties in PEDOT:PSS, various chemical treatments have been carried out to control the electronic properties, which included the use of different organic solvents such as ethanol, dimethylsulfoxide, acetonitrile, and tetra-hydrofuran $[10,11]$. Ouyang and co-workers have studied the effect of various salts on PEDOT:PSS conductivity, and the study revealed that the conductivity could be enhanced by employing metal salts as dopants due to the binding of the metal ions to the PSS anions [2, 12]. Alternatively, ethylene glycol (EG) have been explored as dopant material for PEDOT:PSS that is able to increase conductivity $[13,14]$. Ethylene glycol and diethylene glycol (DEG) are both known as polyol material that plays a role in coordinating solvents, complexants, and surfactants which prevents agglomeration affecting electronic properties [15]. Nonetheless, the optimum doping condition of these EG and DEG modified PEDOT:PSS has not been reported.

Hence, this study aims at developing the novel architecture of inverted PSC and investigating the effect of modification on the hole transport materials, i.e., PEDOT:PSS, using EG and DEG at various doping concentration to the performance of the solar cell. The inverted PSC here was designed bearing $\mathrm{CaTiO}_{3}$ as the active layer since, among various perovskite materials, $\mathrm{CaTiO}_{3}$ constitutes an alternative to the lead-free based commercial perovskite because of its environmentally friendly properties [16, 17]. This material is well known for its high dielectric, luminescent, and semiconductor properties [18]. The optical properties of $\mathrm{CaTiO}_{3}$ can be tuned by modification of the precursors, which in this work a mixture of $\mathrm{CaCO}_{3}$ and $\mathrm{TiO}_{2}$ at different ratios was used for preparation via wet chemical routes. Finally, solar cell performance by combining modified PEDOT:PSS and $\mathrm{CaTiO}_{3}$ as well as photoresponse as UV photodetector is presented. 


\section{Experimentals}

\subsection{Materials and synthesis of $\mathrm{CaTiO}_{3}$}

The materials used were the commercial $\mathrm{CaCO}_{3}$, and anatase $\mathrm{TiO}_{2}$ powder (MTI, $99 \%$ ), Solvents used were $96 \%$ ethanol (analytical grade) and distilled water. Mixtures of $\mathrm{CaCO}_{3}$ and $\mathrm{TiO}_{2}$ powder with $\mathrm{CaCO}_{3} / \mathrm{TiO}_{2}$ molar ratio of $1: 1,1: 3$, and $1: 7$ were prepared. $\mathrm{A}$ mixture was dissolved in $100 \mathrm{~mL}$ of ethanol and homogenized by continuous stirring at $300 \mathrm{rpm}(\mathrm{rpm}=1 / 60 \mathrm{~Hz})$ for $2 \mathrm{~h}$ at room temperature. The solution was then washed with distilled water several times and dried in an oven at $100{ }^{\circ} \mathrm{C}$ for $2 \mathrm{~h}$ to obtain the white powder. The resulting white powder was subsequently ground into fine and homogeneous granules. Finally, the powder was annealed at $700{ }^{\circ} \mathrm{C}$ and $900{ }^{\circ} \mathrm{C}$ for $2 \mathrm{~h}$.

\subsection{Fabrication of $\mathrm{CaTiO}_{3}$ solar cell and UV photodetector}

Indium-doped tin oxide (ITO) on glass substrate was used as active layer to prepare thin film. For electron transport layer (ETL), PCBM-C70 was dissolved into chlorobenzene, droped using micropipet onto ITO glass, and spin coated at $5000 \mathrm{rpm}$ for $30 \mathrm{~s}$. The ETL layer was then dried on the heating plate at $120{ }^{\circ} \mathrm{C}$ for $15 \mathrm{~min}$. As prepared $\mathrm{CaTiO}_{3}$ was dissolved into ethanol (EtOH) to form paste/slurry. The $\mathrm{CaTiO}_{3}$ was dropped and spin coated at $5500 \mathrm{rpm}$ for $30 \mathrm{~s}$ and dried on the heating plate at $120{ }^{\circ} \mathrm{C}$ for $10 \mathrm{~min}$. The obtained layers were then coated with either pristine PEDOT:PSS or modified PEDOT:PSS at $7000 \mathrm{rpm}$ for $30 \mathrm{~s}$. Modification of PEDOT:PSS was carried out by using either ethylene glycol (EG) or diethylene glycol (DEG). As cathode, carbon-coated ITO glass was used.

\subsection{Characterization}

X-ray diffraction (XRD) pattern was obtained using a diffractometer (PAN analytical type $\mathrm{X}$ 'Pert Pro) operated at $40 \mathrm{kV}$, and $40 \mathrm{~mA}$ with $\mathrm{Cu}-\mathrm{K} \alpha$ as a radiation source. Samples were scanned between $10^{\circ}$ and $100^{\circ}(2 \theta)$ with resolutions of $0.05^{\circ}$. Micromorphology of $\mathrm{CaTiO}_{3}$ powder was observed by scanning electron microscopy (SEM, FEI Inspect 21 type) at $100 \mathrm{kV}$ accelerating voltage. Electrochemical impedance characterization of modified PEDOT:PSS was undertaken using potensiostat (VerstaStat II) in two electrode system. FTIR spectra were measured using Thermo-Nicolet FTIR spectrometer. Absorption properties were measured using UV/vis spectrometer (Rayleigh UV-9200). The photovoltaic performance of the $\mathrm{CaTiO}_{3}$ solar cells was determined by measuring photocurrent density-photovoltage $(J-V)$ characteristic curve under diffuse UV-vis irradiation. This $J-V$ measurement was implemented in ambient atmosphere by using an electrochemical measurement system to control the voltage and current. The light-toelectrical energy conversion efficiency $(\eta)$ of the solar cell were calculated according to the Equations (1):

$$
\eta=\frac{F F \times V_{o c} \times I_{s c}}{P_{\text {in }}}
$$

where $I_{S C}$ is the short-circuit current $(\mathrm{mA}), \mathrm{V}_{\mathrm{OC}}$ is the open-circuit voltage $(\mathrm{V}), \mathrm{P}_{\text {in }}$ is the incident light power (Watt), and FF is the fill factor. 


\section{Results and discussions}

Figure 1 shows $\mathrm{SEM}$ images of $\mathrm{CaTiO}_{3}$ with composition variation of $\mathrm{CaCO}_{3} / \mathrm{TiO}_{2}(1: 1$ and 1:7) upon calcination at $900{ }^{\circ} \mathrm{C}$. It is clear that the morphology of $\mathrm{CaTiO}_{3}$ particle is semispherical with non uniform particle size and is relatively aggregated. The particle size distribution indicates that increasing molar composition of $\mathrm{TiO}_{2}$ in $\mathrm{CaCO}_{3} / \mathrm{TiO}_{2}$ from (1:1) to (1:7) under high calcination temperature yields smaller crystallite size. In addition, the resulting $\mathrm{CaTiO}_{3}$ particles prepared using higher $\mathrm{TiO}_{2}$ content tend to be more stable than that using lower $\mathrm{TiO}_{2}$ content as well as yield less aggregated morphology. In contrast with the $\mathrm{CaTiO}_{3}$ prepared via solid-state reaction, the heat treatment at high-temperature capable of changing the structural properties of wet-chemically synthesized $\mathrm{CaTiO}_{3}$ as indicated by inhomogeneity in its final forms [19].
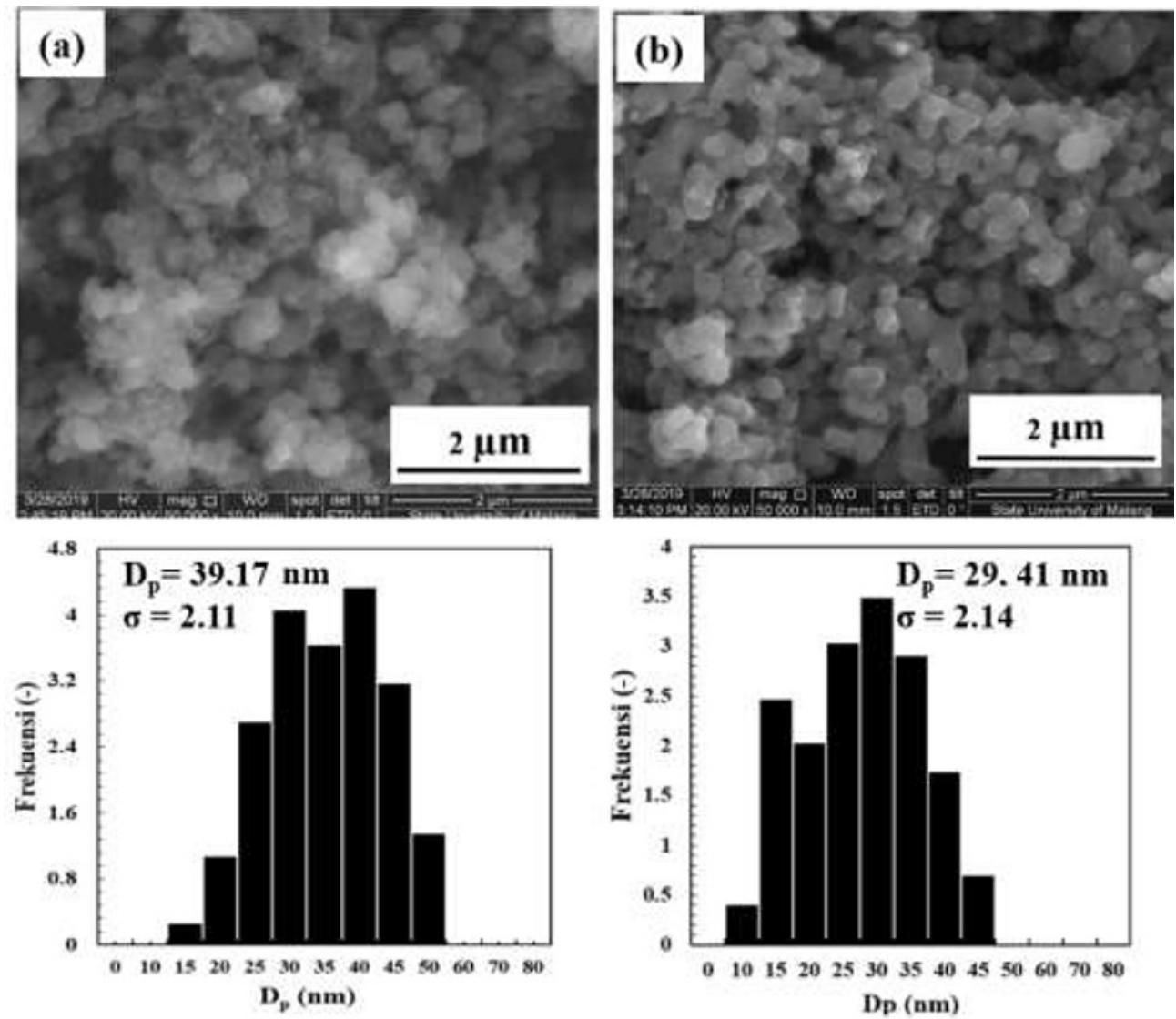

Fig. 1. Morphology of $\mathrm{CaTiO}_{3}$ with different compositions of $\mathrm{CaCO}_{3} / \mathrm{TiO}_{2}$ (a) $1: 1, \mathrm{~T}=900{ }^{\circ} \mathrm{C}$ and (b) $1: 7, \mathrm{~T}=900^{\circ} \mathrm{C}$.

Electronic properties of $\mathrm{CaTiO}_{3}$ is further assessed from the X-ray diffraction (XRD) pattern. Figure 2 shows the resultant XRD spectra of $\mathrm{CaTiO}_{3}$ prepared under different conditions, which are referenced to the standard peak intensities of $\mathrm{CaCO}_{3}, \mathrm{TiO}_{2}$, and $\mathrm{CaTiO}_{3}$. The decrease of peak intensities (diffraction maximum) as well as the peak broadening in $\mathrm{CaCO}_{3}$ indicates the deformation of its crystal structure, i.e., crystal structure defects induce high crystal lattice strain [20]. These broadening peaks also indicate that 
$\mathrm{CaCO}_{3}$ and $\mathrm{TiO}_{2}$ have lower crystallinity degrees. After calcination, X-ray diffraction pattern shows that the $\mathrm{CaTiO}_{3}$ is obtained in all various samples as new peaks at $33.17^{\circ}$, $41.32^{\circ}, 48.11^{\circ}$, and $75.11^{\circ}$ appear which can be referenced to JCPDS No. 96-101-1212 for $\mathrm{CaTiO}_{3}$. The results show that $\mathrm{CaTiO}_{3}$ powder is characterized with orthorhombic structure. In addition, as shown in Figure 2, there exist diffraction peaks of $\mathrm{TiO}_{2}$ and $\mathrm{CaCO}_{3}$ in the $\mathrm{CaTiO}_{3}$ samples indicating that the preparation route was either excessive of precursor concentration or insufficient for mechanical grinding to provide fine precursor nanoparticle.

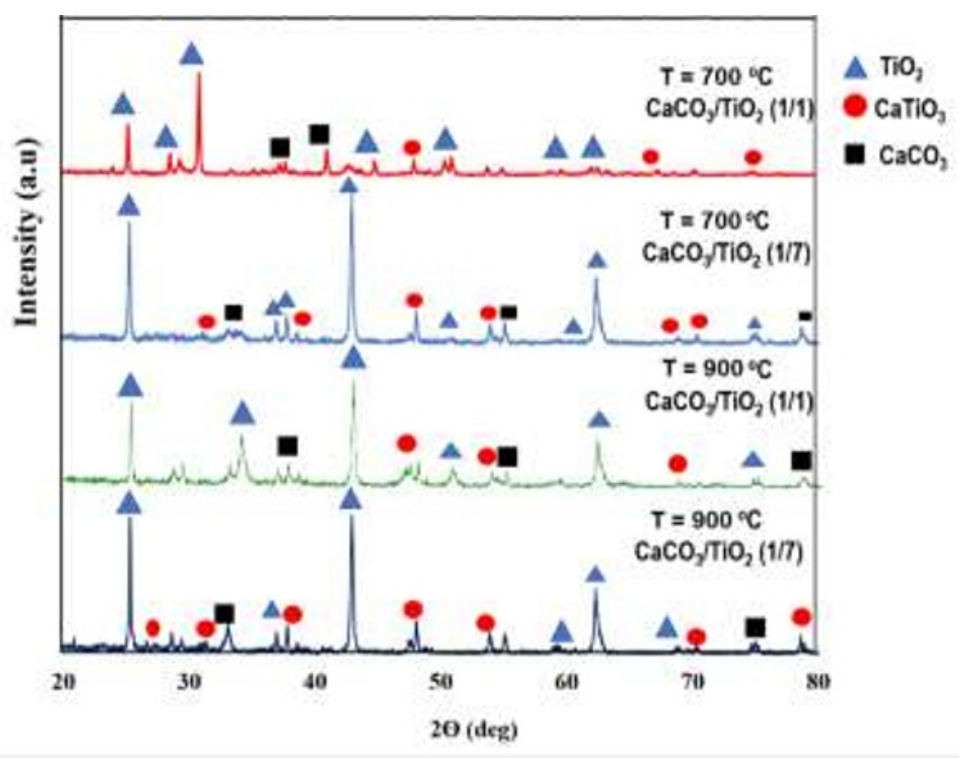

Fig. 2. XRD patterns of $\mathrm{CaTiO}_{3}$ powders with different heating treatment temperature and compositions of $\mathrm{CaCO}_{3}$ and $\mathrm{TiO}_{2}$ for the comparison.

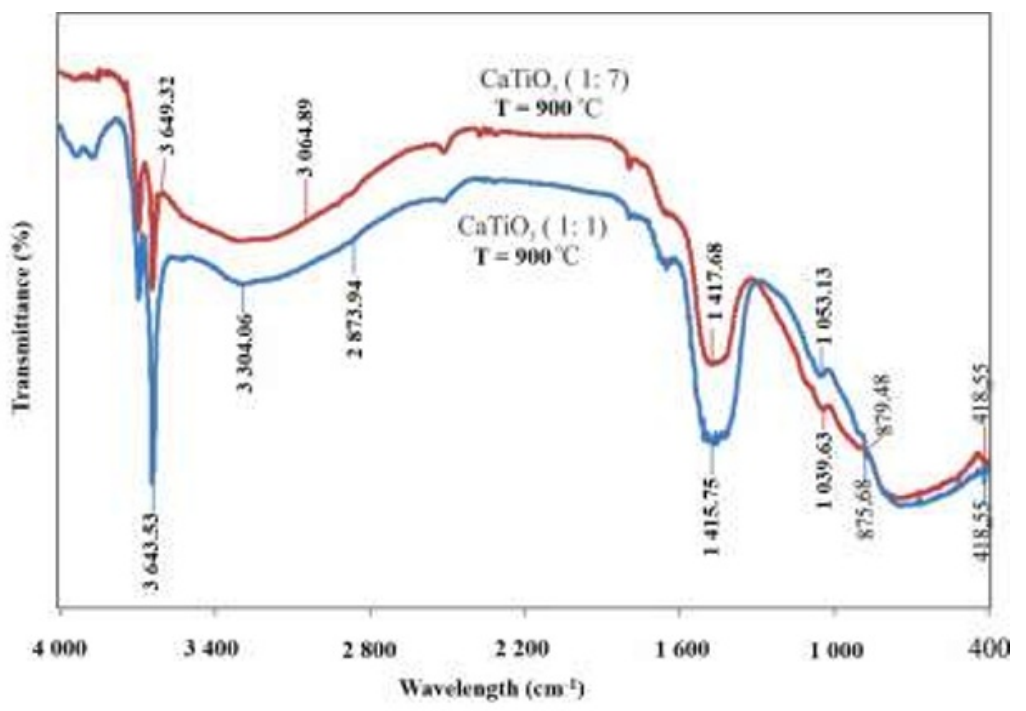

Fig. 3. FTIR spectra of $\mathrm{CaTiO}_{3}$ prepared using different ratio of $\mathrm{CaCO}_{3} / \mathrm{TiO}_{2}$.

In addition, the functional group of $\mathrm{CaTiO}_{3}$ were observed by FTIR analysis, and the results were shown in Figure 3. The IR spectra of $\mathrm{CaTiO}_{3}$ sample with a varied 
$\mathrm{CaCO}_{3} / \mathrm{TiO}_{2}$ ratio $(1: 1)$ and $(1: 7)$ annealed at $900{ }^{\circ} \mathrm{C}$ show bands at $3698 \mathrm{~cm}^{-1}$ and $3642 \mathrm{~cm}^{-1}$. According to the previous report, these peaks are assigned to a vibration characteristic of the hydroxy $(\mathrm{OH})$ group. Moreover, it is indicated that increasing annealing temperature affects the absence of water molecules. The higher calcination temperature $\left(\mathrm{T}=900{ }^{\circ} \mathrm{C}\right)$ can reduce the moisture content of material. The IR spectra also exhibit band at $1422 \mathrm{~cm}^{-1}$ which decreases with increasing $\mathrm{TiO}_{2}$ fraction. According to the previous report, the IR band at $1400 \mathrm{~cm}^{-1}$ shows the asymmetrical and symmetrical vibrations between metal oxide. Hence, it indicates the residual interaction of $\mathrm{CaCO}_{3}$ functional group, which is the bond vibration between $\mathrm{C}-\mathrm{O}$ of $\mathrm{CO}_{3}{ }^{2-}$ ions. The increasing mol ratio of $\mathrm{TiO}_{2}$ increases the absorption area leading to more surface reaction between $\mathrm{TiO}_{2}$ and $\mathrm{CaCO}_{3}$. Therefore, the vibrational spectrum at $1066 \mathrm{~cm}^{-1}$ shows the bond vibration between C-O-Ti groups whilst the IR peaks around $800 \mathrm{~cm}^{-1}$ to $900 \mathrm{~cm}^{-1}$ shows the existence of Ti-O-Ti bond vibration. In addition, the broad absorption at $664 \mathrm{~cm}^{-1}$ indicates the vibration of the Ca-Ti-O group.

Table 1. Estimated of optical band gap for $\mathrm{CaTiO}_{3}$ prepared using different $\mathrm{CaCO}_{3}: \mathrm{TiO}_{2}$ ratio and annealing temperature.

\begin{tabular}{|c|c|c|}
\hline $\mathrm{CaCO}_{3}: \mathrm{TiO}_{2}$ ratio & $\mathrm{Eg} / \mathrm{eV}\left(\mathrm{T}=700{ }^{\circ} \mathrm{C}\right)$ & $\mathrm{Eg} / \mathrm{eV}\left(\mathrm{T}=900{ }^{\circ} \mathrm{C}\right)$ \\
\hline $1: 1$ & 3.98 & 3.69 \\
\hline $1: 3$ & 4.36 & 3.95 \\
\hline $1: 7$ & 4.29 & 4.22 \\
\hline
\end{tabular}
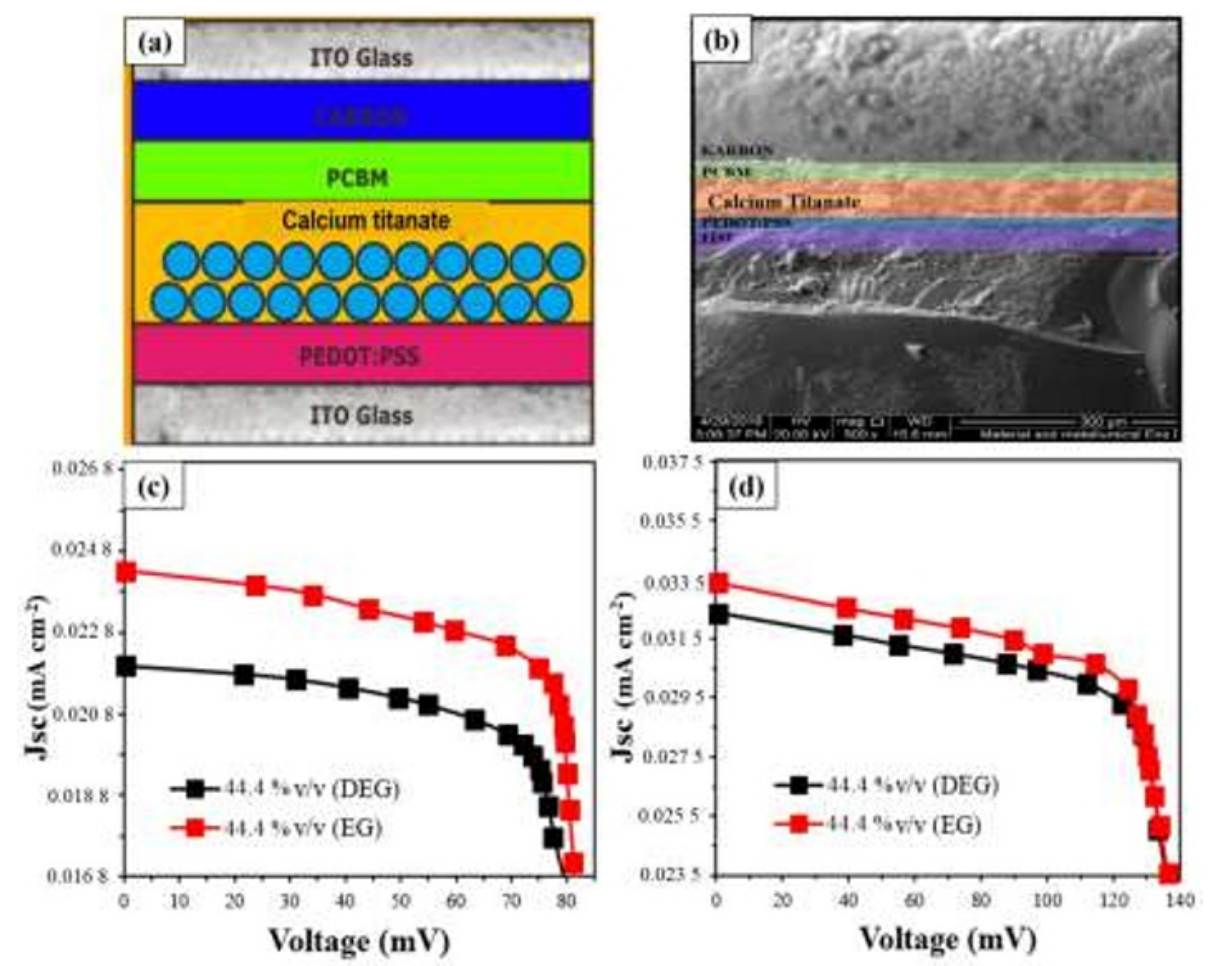

Fig. 4. (a) The device architecture of solar cell, (b) cross-sectional SEM image of the $\mathrm{CaTiO}_{3}$ solar cell. The current density-voltage charactyeristic $(J-V)$ curve of $\mathrm{CaTiO}_{3}$ solar cell bearing modified EDOT:PSS and different composition of $\mathrm{CaCO}_{3} / \mathrm{TiO}_{2}$ (c) $1: 1$ and (d) $1: 7$ annealed at $900{ }^{\circ} \mathrm{C}$.

As discussed earlier, increasing annealing temperature as well as concentration of $\mathrm{TiO}_{2}$ will cause the growth of $\mathrm{CaTiO}_{3}$ crystal. This altered crystallite $\mathrm{CaTiO}_{3}$ structure as 
revealed in XRD analysis in turn affects its optical properties. The optical properties of $\mathrm{CaTiO}_{3}$ are indicated by optical band gap estimated from absorption spectra (using Tauc Plot, Table 1). As seen, it is obvious that $\mathrm{CaCO}_{3} / \mathrm{TiO}_{2}$ ratio and annealing temperature affect the optical band gap, in which higher $\mathrm{TiO}_{2}$ ratio yields higher optical band gap. Meanwhile, higher annealing temperature results in a slightly lower optical band gap due to impaired quantum confinement effects. From this point, we will explore the utilization of CaTiO3 prepared at $900{ }^{\circ} \mathrm{C}$ using $\mathrm{CaCO}_{3} / \mathrm{TiO}_{2}$ ratio (1:1) and (1:7) because of their significant different in optical properties.

Table 2. Solar cell properties derived from current-voltage measurements.

\begin{tabular}{|c|c|c|c|c|c|}
\hline $\mathrm{CaCO}_{3}: \mathrm{TiO}_{2}$ & Modification & Jsc $\left(\mathrm{mA} \mathrm{cm}{ }^{-2}\right)$ & Voc $(\mathrm{mV})$ & FF & $\eta(\%)$ \\
\hline $1: 1$ & EG $-16.7 \%$ & 0.017 & 60 & 0.66 & 0.64 \\
\hline $1: 1$ & EG $-28.6 \%$ & 0.019 & 68 & 0.64 & 0.76 \\
\hline $1: 1$ & EG $-37.5 \%$ & 0.020 & 71 & 0.66 & 0.92 \\
\hline $1: 1$ & EG $-44.4 \%$ & 0.025 & 81 & 0.68 & 1.32 \\
\hline $1: 1$ & DEG $-16.7 \%$ & 0.017 & 62 & 0.65 & 0.65 \\
\hline $1: 1$ & DEG $-28.6 \%$ & 0.020 & 72 & 0.65 & 0.92 \\
\hline $1: 1$ & DEG $-37.5 \%$ & 0.020 & 81 & 0.69 & 1.08 \\
\hline $1: 1$ & DEG $-44.4 \%$ & 0.025 & 84 & 0.69 & 1.42 \\
\hline $1: 7$ & EG $-16.7 \%$ & 0.024 & 90 & 0.75 & 1.54 \\
\hline $1: 7$ & EG $-28.6 \%$ & 0.027 & 119 & 0.60 & 1.82 \\
\hline $1: 7$ & EG $-37.5 \%$ & 0.027 & 119 & 0.66 & 2.02 \\
\hline $1: 7$ & EG $-44.4 \%$ & 0.032 & 136 & 0.67 & 2.58 \\
\hline $1: 7$ & DEG $-16.7 \mathrm{~s} \%$ & 0.025 & 82.2 & 0.79 & 1.57 \\
\hline $1: 7$ & DEG $-28.6 \%$ & 0.027 & 99.2 & 0.73 & 1.90 \\
\hline $1: 7$ & DEG $-37.5 \%$ & 0.032 & 105 & 0.64 & 2.04 \\
\hline $1: 7$ & DEG - 44.4 \% & 0.032 & 136 & 0.67 & 3.11 \\
\hline
\end{tabular}

Figure $4 \mathrm{a}$ and Figure $4 \mathrm{~b}$ show the architecture design and the cross-sectional image of $\mathrm{CaTiO}_{3}$ solar cell, respectively. The solar cell architecture reflects an inverted structure of perovskite solar cell, in which PEDOT:PSS and PCBM-C70 are employed as hole and electron transport material, respectively. Performance of $\mathrm{CaTiO}_{3}$ perovskite solar cells, including cell parameters (open circuit voltage Voc, short circuit current density Jsc, and fill factor FF), is evaluated from current density-voltage ( $\mathrm{J}-\mathrm{V})$ curves measured under diffuse irradiation $\left(\sim 380 \mathrm{~W} \mathrm{~m}^{-2}\right.$, incandescent lamp). As shown in Figure $4 \mathrm{c}$ and Figure $4 \mathrm{~d}$ as well as in Table 2, polyol modification does not significantly alter Voc. However, substitution of $\mathrm{CaTiO}_{3}(1: 1)$ to $(1: 7)$ enhances Voc by $50 \%$ to $100 \%$, which is due to a higher optical band gap for $\mathrm{CaTiO}_{3}(1: 7)$ than $\mathrm{CaTiO}_{3}$ (1:1). Interestingly, the deployment of EG-doped PEDOT:PSS in $\mathrm{CaTiO}_{3}$ solar cells consistently shows slightly lower Jsc than that of DEG-doped PEDOT:PSS. The higher Jsc obtained in solar cell using DEG-doped PEDOT:PSS can be due to the increased hole mobility in PEDOT:PSS: The impedance characterization reveals that hole mobility in PEDOT:PSS $\left(0.45 \mathrm{~cm}^{2} \mathrm{~V}^{-1} \mathrm{~s}^{-1}\right)$ is increased by factor of 1.6 and 2.3 upon modification using EG and DEG, respectively. This results is consistent with literature report $[13,14]$ that EG doping in PEDOT:PSS increases the electron phonon coupling and hence its conductivity. It is known that higher mobility of HTM should lead to a suppressed recombination reaction, a limiting process to generate 
high photocurrent in solar cell. Overall, the best photovoltaic performance in this work exhibit a conversion efficiency $(\eta)$ as high as $3.11 \%$.

As central issue of perovskite solar cell is its stability, the effect of PEDOT:PSS modification toward stability of $\mathrm{CaTiO}_{3}$ solar cell efficiency is assessed (Figure 5a) upon aging for $3 \mathrm{~d}$ under ambient condition with $60 \%$ relative humidity. Without polyol modification, solar cell efficiency drops down to $7 \%$ of its initial magnitude. Polyol modification of PEDOT:PSS, irrespective of dopant materials, enables maintaining $40 \%$ of initial efficiency. Nevertheless, it should be noted that solar cells using EG-doped PEDOT:PSS reveal a slower degradation rate. To further confirm the origin of photo response, the optoelectrical properties have been investigated as UV photodetector (Figure 5b). The present device exhibits a sharp on/off transition in the photocurrent with good stability and reproducibility upon UV-lamp exposure $\left(365 \mathrm{~nm}, \sim 100 \mathrm{~mW} \mathrm{~cm}^{-2}\right)$. The photocurrent different between dark and UV irradiated is $2.5 \mu \mathrm{A} \mathrm{cm}{ }^{-2}$, i.e., one order of magnitude lower than the obtained Jsc. This result is plausible since the perovskite $\mathrm{CaTiO}_{3}$ strongly absorbs deep UV region $<300 \mathrm{~nm}$. In addition, the transient behaviors of current density of $\mathrm{CaTiO}_{3}$ solar cell (Figure 5c and Figure 5d) is investigated to indicate the sensitivity. The rising and decaying time is found $c a .5 \mathrm{~s}$, which is relatively slow for rapid UV photodetection. Therefore, further optimization is required, particularly to enhance the sensitivity of photodetection.
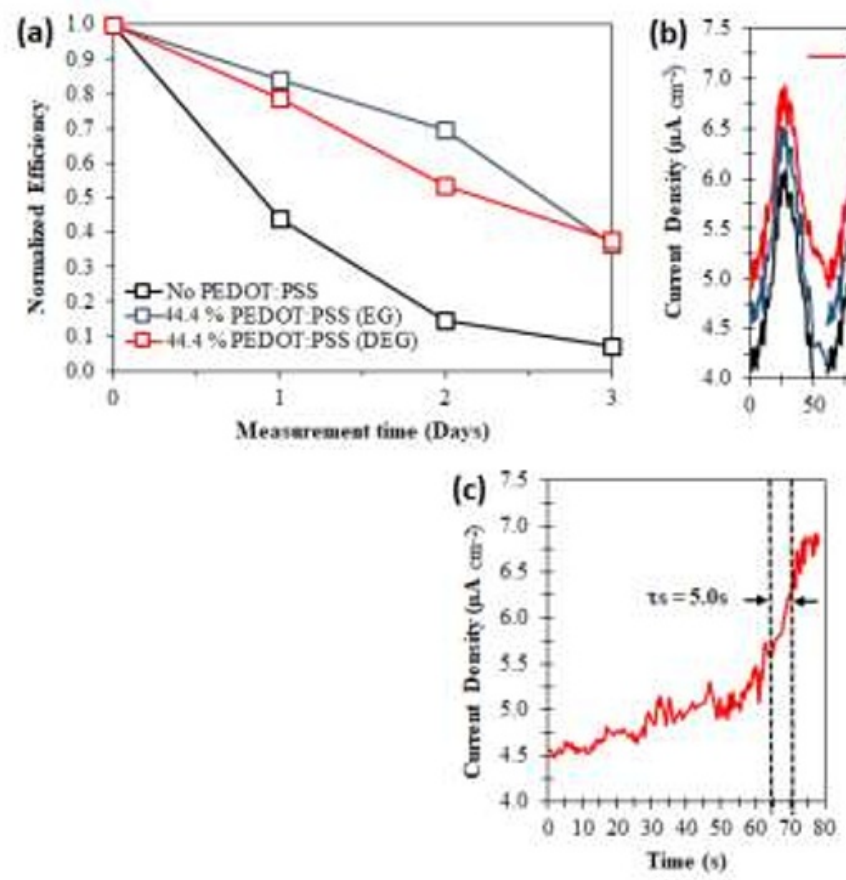
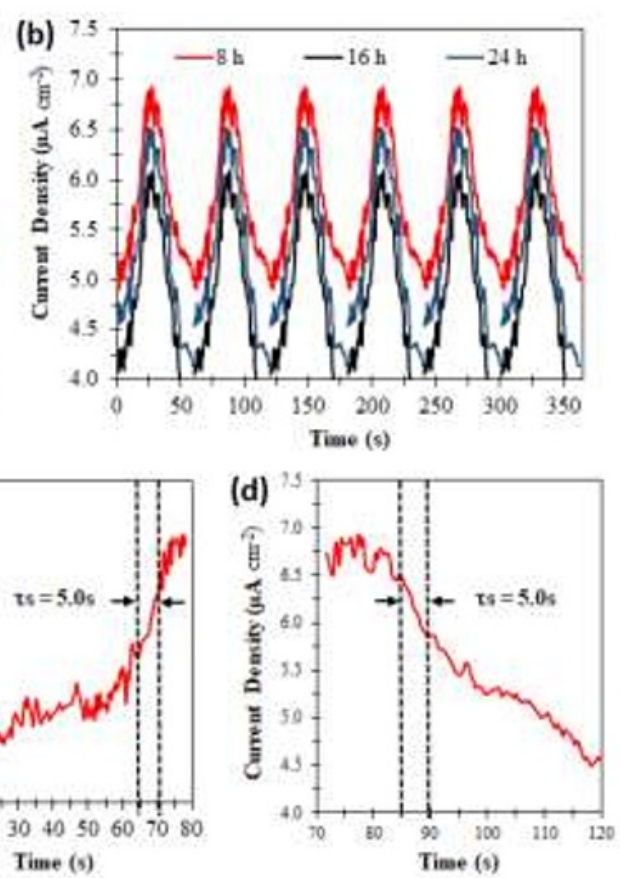

Fig. 5. (a) Efficiency of $\mathrm{CaTiO}_{3}$ solar cells and (b) chopped light UV photocurrent response upon aging for days and hours, respectively. Rising (c) and decaying (d) current response upon UV irradiation. 


\section{Conclusion}

This research have demonstrated that the novel inverted architecture of $\mathrm{CaTiO}_{3}$-based solar cell using PEDOT:PSS as hole transport material functionally works. Polyol modification by either EG or DEG doping significantly enhances the charge mobility in PEDOT:PSS and affects the current generation in solar cell upon irradiation. The optimum conditions of $\mathrm{CaTiO}_{3}$ solar cell was achieved by using $\mathrm{CaTiO}_{3}$ particles prepared using $\mathrm{CaCO}_{3} / \mathrm{TiO}_{2}$ ratio of (1:7) annealed at $900{ }^{\circ} \mathrm{C}$ and $44.4 \%$ DEG-modified PEDOT:PSS. The power efficiency obtained under diffuse illumination is $2.58 \%$. The improvement in the electrophysical properties of PEDOT:PSS as the hole transport layer combined with PCBM-C70 proved to be key factors towards enhancing the $\mathrm{CaTiO}_{3}$ solar cells. These improvements include a significantly improved stability of power conversion effeciency upon aging $72 \mathrm{~h}$. In addition, the novel design also performs sensitive UV photoresponse even upon irradiation at UV region with lower energy excitation.

Technical assistance from Central Mineral and Advanced Material Laboratory of Malang State University and Bandung Institute of Technology for samples characterization is gratefully acknowledged. This work was financially supported by Science Technology Ressearch Grant, Indonesia Toray Science and Foundation (ITSF).

\section{References}

1. G.K. Singh. Energy, 53:1-13(2013).

https://www.sciencedirect.com/science/article/abs/pii/S0360544213001758

2. K. Sun., S. Zhang. P. Li., Y. Xia. Z. Zhang., D. Du, et al. J. Mater. Science: Mater. Electronics, 26,7:4438-4462(2015). https://link.springer.com/article/10.1007/s10854$\underline{015-2895-5}$

3. X. Zhang, D. Yang., Z. Yang., X. Guo, B. Liu., X. Ren, et al. Scientific Reports, 6,35091:(2016). https://www.nature.com/articles/srep35091

4. D. Alemu., Y.W. Hung., C.H. Kuo, W.C. Chih, Energy Environ. Sci., 5:96629671(2012).

https://pubs.rsc.org/en/content/articlelanding/2012/ee/c2ee22595f\#!divAbstract

5. S. Jackle, M. Liebhaber, C. Gersmann, M. Mews, K. Jager, S. Christiansen, et al. Scientific Reports, 7,2170:1-8(2017). https://www.nature.com/articles/s41598-01701946-3

6. P. Singh, S.K. Srivastava, B. Sivaiah, P. Prathap. C.M.S. Rauthan, Solar energy, 170:221-233(2018). https://www.sciencedirect.com/science/article/abs/pii/S0038092X1830481X

7. Z.A. King, C.M. Shaw, S.A, Spanninga, D.C. Martin, J. Polymer, 52,5:13021308(2011). https://pubmed.ncbi.nlm.nih.gov/21394224/

8. Z.H. Feng, Y.B. Hou, Q.M. Shi, L.F. Qin, L. Yan, Z. Lei, et al. IOP Science: Chinesse Physics B, 19,3:(2010). https://iopscience.iop.org/article/10.1088/1674$1056 / 19 / 3 / 038601 /$ meta

9. S.H. Eom, H. Park, S.H. Mujawar, S.C. Yoon, S.K. Seok, J.K. Seok, et al. Org. Electron., 11,9:1516-1522(2010).

https://www.sciencedirect.com/science/article/abs/pii/S1566119910001953

10. E. Dauzon, A.E. Mansour, M.R. Niazi, R. Munir, D.M. Smilgies, X. Sallenave, et al. ACS. Appl. Mater. Interfaces, 11,19:17570-17582(2019).

https://pubs.acs.org/doi/10.1021/acsami.9b00934 
11. B. Xu, S.A. Gopalan, A.L. Gopalan, N. Muthuchamy, K.P. Lee, J.S.Lee, et al. Scientific Reports, 7,45079:1-13(2017). https://www.nature.com/articles/srep45079/

12. J. Ouyang. Displays 34,5:423-436(2013). https://www.sciencedirect.com/science/article/abs/pii/S0141938213000668

13. H.Q. Cui, R.X. Peng, W. Song, J.F. Zhang, J.M. Huang, L.Q. Zhu, Z.Y. Ge. Chinese J. Polym. Sci., 37:760-766(2019). https://link.springer.com/article/10.1007/s10118$\underline{019-2257-5}$

14. Y.J. Lin, W.S. Ni, J.Y. Lee. J. Appl. Phys., 117,215501:(2015). https://aip.scitation.org/doi/abs/10.1063/1.4921930?journalCode=jap

15. M. Hosni, I. Hinkov, C. Ricolleau, T. Pauporte, S. Farhat, N. Jouini. J. Surf. Eng. Mater. Adv. Technol., 6,1:1-10(2016). https://file.scirp.org/Html/1-1180314_63692.htm

16. I.R. Evans, J.A. Howard, T. Sreckovic, M.M. Ristic. Mater. Res. Bull., 38,7:12031213(2003). https://www.sciencedirect.com/science/article/pii/S0025540803001132

17. A.A.A. Torimtubun, A.C. Augusty, E. Maulana, L. Ernawati. E3S Web Conf., 67,01010:1-6(2018).

https://www.e3s-conferences.org/articles/e3sconf/abs/2018/42/e3sconf_itrec2018_01010/e3sconf_i-trec2018_01010.html

18. S.J. Lee, Y.C. Kim, J.H. Hwang. J. Ceram. Process. Res., 5,3:223-226(2004). https://www.researchgate.net/publication/283632194_An_organicinorganic solution technique for fabrication of nano-sized CaTiO3 powder

19. A.G. Evans. J. American Ceramic Society, 65,10:497-501(1982). https://ceramics.onlinelibrary.wiley.com/doi/abs/10.1111/j.11512916.1982.tb10340.x

20. Y. Wang, L. Chen, G. Yuan, H. Luo, J. Li, D. Viehland. Scientific Reports, 6,35120:1-9(2016). https://www.nature.com/articles/srep35120 